\title{
Pelvic symptoms after radiotherapy in prostate cancer: a cross-sectional study
}

\author{
Sintomas pélvicos após radioterapia para o câncer \\ de próstata: um estudo transversal
}

\begin{abstract}
Aline Moreira Ribeiro ${ }^{[a]}$, Fernanda Maris Peria ${ }^{[a]}$, Elaine Cristine Lemes Mateus-Vasconcelos ${ }^{[b]}$, Cristine Homsi Jorge Ferreira ${ }^{[a]}$, Valdair Francisco Mugliaa $^{[a]}$, Harley Francisco de Oliveira ${ }^{[a]^{*}}$
\end{abstract}

[a] Universidade de São Paulo (USP), Ribeirão Preto, SP, Brazil

[b] Centro Universitário Barão de Mauá (CBM), Ribeirão Preto, SP, Brazil

\begin{abstract}
Introduction: Despite the technical and scientific progress that improved therapeutic resources available in Oncology, adverse effects of treatment can be prominent, impacting the quality of life (QoL). Objective: This research aims to determine the prevalence of post-radiotherapy pelvic symptoms in prostate cancer (PC) and its impact on QoL. Methods: We assessed three groups of patients at different stages during radiotherapy (RT): Pre-RT, evaluated before of RT; Post-RT\#1, evaluated between six months and one year post-RT; Post-RT\#2, evaluated between two and a half and four years post-RT. The presence of urinary incontinence (UI), its characteristics and impact on daily living activities (DLA) were evaluated by ICIQ-SF questionnaire. WHOQOL-BREF questionnaire was used to assess QoL. Student t test was used, considering significant $\mathrm{p}<0.05$. Results: Thirty-three men were assessed (pre-RT, $n=12$; Post-RT\#1, $n=10$; Post-RT\#2, $n=11$ ). The prevalence of lower urinary tract symptoms (LUTS) was highest in Post-RT\#1 group. Post-RT\#2 group had the highest
\end{abstract}

\footnotetext{
* RAM: Doctoral student, e-mail: alinemrib@gmail.com PFM: PhD, e-mail: fernandaperia@fmrp.usp.br MVECL: PhD, e-mail: elainelemes@baraodemaua.br FCHJ: PhD, e-mail: cristine@fmrp.usp.br MVF: PhD, e-mail: fmuglia@fmrp.usp.br OHF: PhD, e-mail: harley@fmrp.usp.br
} 
prevalence of post-RT UI. In QoL, Pre-RT and Post-RT\#2 groups experiencing the greatest impact on physical, environmental and overall QoL. Conclusion: Acute effect of RT is characterized by a high prevalence of LUTS. Post-RT\#2 group experienced the most adverse effects on DLA due to a higher prevalence of post-RT UI.

Keywords: Prostatic Cancer. Radiotherapy. Urinary Incontinence. Quality of Life.

\section{Resumo}

Introdução: Apesar do progresso técnico e científico que melhorou recursos terapêuticos disponíveis na Oncologia, efeitos adversos do tratamento podem ser proeminentes, impactando a qualidade de vida (QoL). Objetivo: Esta pesquisa tem como objetivo determinar a prevalência de sintomas pélvicos pós-radioterapia no câncer de próstata (CaP) e seu impacto na QoL. Métodos: Avaliou-se três grupos de pacientes com CaP em diferentes estágios da radioterapia (RT): (1) Pré-RT, avaliados antes da RT; (2) Pós-RT \#1, avaliados entre seis meses e um ano pós-RT; (3) Pós-RT \#2, avaliados entre dois anos e meio e quatro anos pós-RT. A presença de incontinência urinária (IU), suas características e o impacto sobre as atividades da vida diária (AVD) foram avaliados através do questionário ICIQ-SF. O questionário WHOQOL-BREF foi utilizado para avaliar a QoL. O teste t de Student foi utilizado para análise estatística, considerando significativo $p<0,05$. Resultados: Trinta e três homens foram avaliados (pré-RT, $n=12$; Pós-RT \#1, $n=10$; Pós-RT \#2, $n=11$ ). A prevalência de sintomas do trato urinário inferior (STUI) foi maior no grupo Pós-RT \#1. O grupo Pós-RT \#2 teve a maior prevalência de IU pós RT. Na avaliação da QoL, os grupos Pré-RT e Pós-RT \#2 apresentaram maior impacto negativo sobre os índices relacionados aos quesitos físico, ambiental e global. Conclusão: $O$ efeito agudo da RT foi caracterizado por uma elevada prevalência de STUI. O grupo Pós-RT \#2 experimentaram maior impacto negativo as AVD, devido a uma maior prevalência de IU pós RT.

Palavras-chave: Câncer da Próstata. Radioterapia. Incontinência Urinária. Qualidade de Vida.

\section{Introduction}

Cancer has transformed its original characteristic of disease prevalent in developed countries. In the last four decades, it has become a global public health problem, especially among developing countries, where it is expected that in the coming decades the impact of cancer on the population will account for $80 \%$ of the estimated 20 million new cases by 2025 [1].

In Brazil, preliminary data for 2016 indicates the occurrence of about 596,070 new cases of cancer. Prostate cancer (PC) is one of the most prevalent cancers in men, excluding nonmelanoma skin tumor, with an incidence estimated in 61,200 new cases [1].

D'Amico et al. [2] estimated the risk of biochemical recurrence in localized $\mathrm{CaP}$ using serum levels of prostatic specific antigen (PSA) and Gleason score levels, a histopathological analysis of the fragments collected in the biopsy. Three risk classes were defined as low (PSA $\leq 10 \mathrm{ng} / \mathrm{mL}$ and Gleason score $\leq 6$ ), intermediate (PSA
$>10$ and $\leq 20 \mathrm{ng} / \mathrm{mL}$ and Gleason score 7) and high (PSA > 20ng / $\mathrm{mL}$ and Gleason score $\geq 8$ ).

As a basic rule, considering the patient's life expectancy in low-risk PC, the therapeutic possibilities are active surveillance, radical prostatectomy (PR) and RT or brachytherapy (BQT) [3]. At intermediate risk, hormone therapy (HT) combined with RT, BQT or PR are acceptable therapeutic options. In the treatment of high-risk cancer, the best treatment options are the combination of HT and RT, or PR followed by RT [4]. Data from Surveillance, Epidemiology and End Results (SEER) showed that, in general, 33.9\% of patients were submitted to conservative treatment, 29.6\% underwent PR and 36.5\% underwent RT [5].

Radiotherapy (RT) has been shown to improve local control and biochemical recurrence-free survival. It is critical in the treatment of prostate cancer (PC). However, some adverse effects to radiation are expected. The most common complications from the various RT treatments include urinary, anorectal, and 
sexual dysfunction. These side effects are attributed to acute and chronic radiation injuries to the rectum, bladder, and other pelvic organs. These present not only as mucositis, but also as functional disorders, erectile activity, bladder or rectal continence, direct injury to the sphincter, or radiation neuritis involving the sacral plexus and nerves [6 - 8].

Acute side effects of RT are usually short-term and treatable with medication but late complications can lead to damage that is difficult to reverse, impairing the quality of life (QoL). In addition to the physiological repercussions, post-RT pelvic symptoms may restrict daily living activities (DLA), social interactions, and self-perception of health. The greatest problems are related to social and mental well-being, which may have psychological, physical, professional, social, and sexual repercussions with a significant impact on QoL $[9,10]$.

The hypothesis of this study was that men receiving RT for PC have a high prevalence of lower urinary tract symptoms (LUTS), anorectal, and sexual complaints compared to men who did not receive RT. The longer the time after RT, the higher the prevalence of these pelvic symptoms and lower the QoL. The aim of this study was, therefore, to determine the prevalence of pelvic symptoms post-RT in PC patients and the impact on QoL.

\section{Methods}

Design of the study

Cross-sectional study.

\section{Context}

Volunteer recruitment and data collection were performed at the Clinical Hospital of the Medical School of Ribeirão Preto, University of São Paulo (HCFMRP-USP) from August to October 2013.

\section{Subjects}

Volunteer recruitment was conducted through a survey of all patients referred to the Radiotherapy Division of HCFMRP-USP for PC treatment by a temporal sequence of aftercare service. Men over the age of 45 years with a diagnosis of PC confirmed by clinical examination and biopsy, and assigned to RT were evaluated for the study. We excluded men with anatomical alterations in the perineal region due to sequelae of surgery, disease, trauma, or local lesions; associated neurological diseases; incomplete RT regimen; or those who had previously undergone of the pelvic floor muscles training (PFMT) or another treatment for the management of pelvic symptoms.

\section{Study groups}

Volunteer recruitment was based on the periods set for the study, in which the patients were divided into three groups:

a) Pre-RT group: patients with indication for RT, non-treated, evaluated before starting treatment;

b) Post-RT \#1 group: patients treated, with a period of six months and one year post-RT;

c) Post-RT \#2 group: patients treated, with a period of two and a half and four years post-RT;

Sample Size

A convenience sample was used for this study.

Variables

This study evaluated men diagnosed with PC with a recommendation for treatment by RT alone or concomitant with other cancer treatments, namely radical prostatectomy (RP) and hormone therapy (HT). Regardless of the group assigned, each volunteer was subjected to the same tests performed by the same physiotherapist.

\section{Evaluation of urinary, anorectal, and sexual} complaints

The volunteer's medical history and sociodemographic and personal data, as comorbidities, age, weight, height, scholarity, colour, marital status and health habits, were obtained. Urological, anorectal, and sexual history were obtained through the medical records analysis and confirmed with the volunteers during the interview. 
Evaluation of the state of urinary continence and impact of incontinence on daily living activities

The International Consultation on Incontinence Questionnaire - Short Form (ICIQ-SF) in Portuguese was used to evaluate the patient's urinary continence and impact of urinary incontinence (UI) on DLA. This questionnaire was translated into Portuguese and validated for both sexes [11].

Assessment of quality of life

The patient also answered a questionnaire to assess QoL, the World Health Organization Quality of Life - Brief (WHOQOL-BREF) [12].

Statistical analysis

For analysis between groups, we used the Student t test, considered statistically significant at $\mathrm{p}<0.05$.
Ethical aspects

This research was referred to and approved by the Research Ethics Committee of HCFMRP-USP (HCRP $\left.\mathrm{n}^{\circ} 3014 / 2013\right)$.

\section{Results}

Subjects

Of the 69 patients enrolled in the study, only 33 were included (Figure 1).

\section{Descriptive data}

The sociodemographic and personal data are in the Table 1. There were no significant differences in age and body mass index (BMI) between the groups $(p=0.4)$.

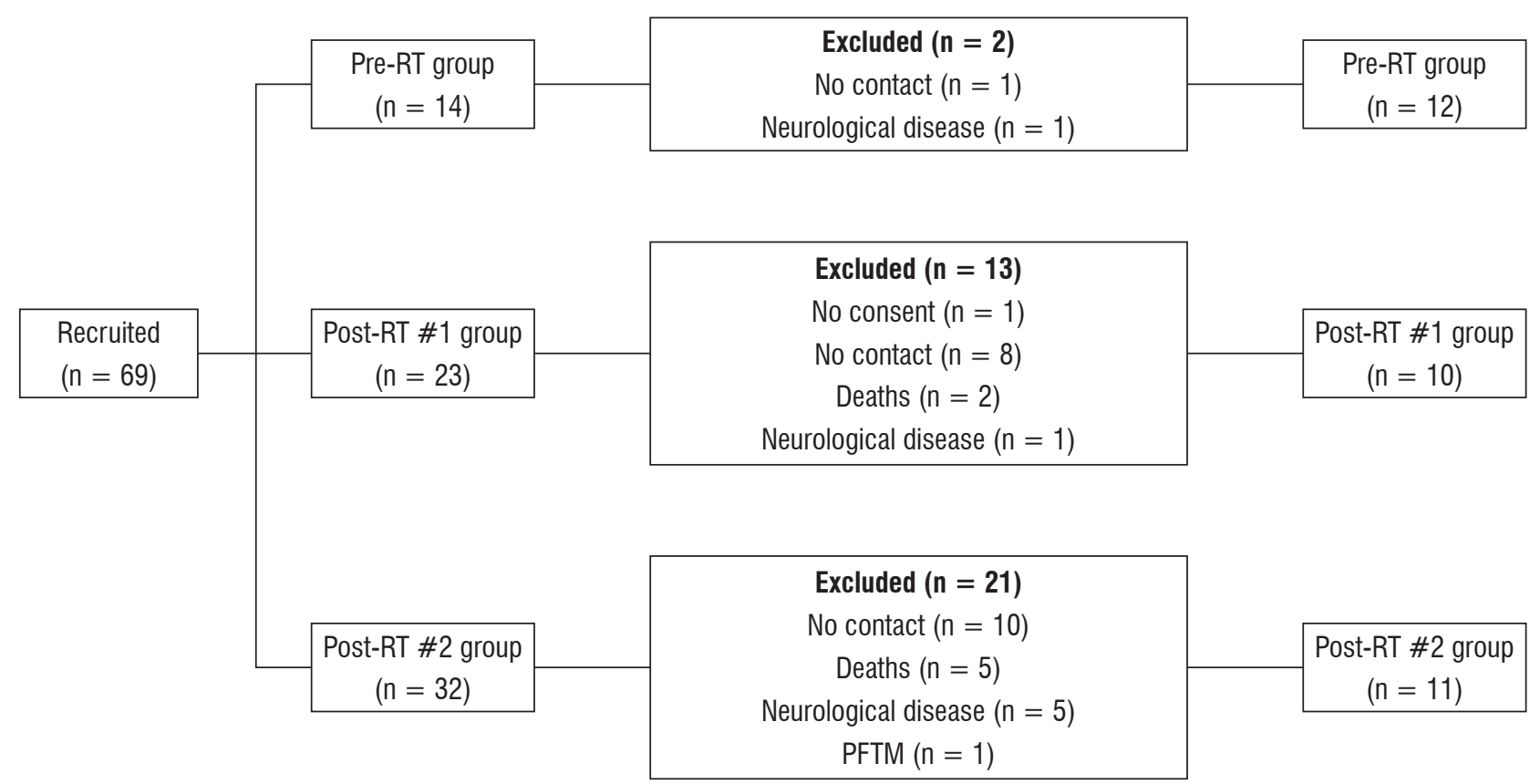

Figure $\mathbf{1}$ - Flow chart of recruited and excluded patients in the study, separated by groups. Note: PFMT: pelvic floor muscles training; RT, radiotherapy. 
Table 1 - Sociodemographic and personal data [mean \pm SD;

\begin{tabular}{|c|c|c|c|}
\hline & $\begin{array}{l}\text { Pre-RT } \\
\text { group } \\
(n=12)\end{array}$ & $\begin{array}{c}\text { Post-RT \#1 } \\
\text { group } \\
(n=10)\end{array}$ & $\begin{array}{c}\text { Post-RT \#2 } \\
\text { group } \\
(n=11)\end{array}$ \\
\hline \multirow[t]{2}{*}{ Age (years) } & $71.4 \pm 1.9$ & $67.5 \pm 3.1$ & $70.5 \pm 2.2$ \\
\hline & (61-81 years) & (51-79 years) & (59-81 years) \\
\hline BMI $\left(\mathrm{kg} / \mathrm{m}^{2}\right)$ & $27.9 \pm 1.7$ & $29.8 \pm 1.8$ & $26.3 \pm 1.3$ \\
\hline \multicolumn{4}{|l|}{ Scholarity } \\
\hline Illiterate & $4(33,3)$ & $1(10)$ & $2(18,2)$ \\
\hline Primary school & $7(58,3)$ & $7(70)$ & $7(63,6)$ \\
\hline Middle school & $1(8,3)$ & $1(10)$ & $0(0)$ \\
\hline Technical school & $0(0)$ & $1(10)$ & $0(0)$ \\
\hline Higher education & $0(0)$ & $0(0)$ & $2(18,2)$ \\
\hline \multicolumn{4}{|l|}{ Marital status } \\
\hline Single & $0(0)$ & $1(10)$ & $0(0)$ \\
\hline Married & $9(75)$ & $9(90)$ & $6(54,5)$ \\
\hline Divorced & $2(16,7)$ & $0(0)$ & $4(36,4)$ \\
\hline Widower & $1(8,3)$ & $0(0)$ & $1(9,1)$ \\
\hline \multicolumn{4}{|l|}{ Colour } \\
\hline White & $9(75)$ & $8(80)$ & $8(72,7)$ \\
\hline Black & $3(25)$ & $2(20)$ & $3(27,3)$ \\
\hline Yellow & $0(0)$ & $0(0)$ & $0(0)$ \\
\hline \multicolumn{4}{|l|}{ Comorbidities } \\
\hline Hypertension & $8(66,7)$ & $6(60)$ & $5(45,5)$ \\
\hline Diabetes mellitus & $2(16,7)$ & $1(10)$ & $2(18,2)$ \\
\hline \multicolumn{4}{|l|}{ Health habits } \\
\hline Sedentary lifestyle & $10(83,3)$ & $5(50)$ & $11(100)$ \\
\hline Alcoholism & $1(8,3)$ & $3(30)$ & $6(54,5)$ \\
\hline Smoking & $3(25)$ & $1(10)$ & $2(18,2)$ \\
\hline
\end{tabular}

Note: BMI: body mass index.
Information related to cancer and cancer treatment are summarized in Table 2.

Table 2 - Information related to the characterization of PC and cancer treatment [mean \pm SD; $n$ (\%); (range)]

\begin{tabular}{lccc}
\hline & $\begin{array}{c}\text { Pre-RT } \\
\text { group } \\
(n=12)\end{array}$ & $\begin{array}{c}\text { Post-RT \#1 } \\
\text { group } \\
(n=10)\end{array}$ & $\begin{array}{c}\text { Post-RT \#2 } \\
\text { group } \\
(n=11)\end{array}$ \\
\hline PSA (ng/mL) & $23.8 \pm 4.0$ & $10.1 \pm 2.2$ & $23.7 \pm 8.0$ \\
Risk & $1(8.3)$ & $6(60)$ & $4(36.4)$ \\
Low & $2(16.7)$ & $2(20)$ & $3(27.3)$ \\
Intermediate & $9(75)$ & $2(20)$ & $4(36.4)$ \\
High & $1(8.3)$ & $4(40)$ & $3(27.3)$ \\
Prostatectomy & $2(16.7)$ & $3(30)$ & $0(0)$ \\
TURP & $11(91.7)$ & $3(30)$ & $7(63.6)$ \\
Hormone therapy & & & \\
Radiotherapy & & $244.1 \pm 12.9$ & $1129.9 \pm 37.6$ \\
Post-RT time (days) & - & $(157-287)$ & $(929-1389)$ \\
& - & 8.0 & 37.2 \\
Post-RT time (month) & - & $71.6 \pm 0.8$ & $74.6 \pm 1.2$ \\
Dose (Gy) & - &
\end{tabular}

Note: PSA, prostate-specific antigen; RT, radiotherapy; TURP, transurethral resection of the prostate.

\section{Outcomes}

Prevalence of urinary, anorectal, and sexual complaints

Table 3 below summarizes information regarding pre and post-RT pelvic symptoms. The term "irritative" included complaints of the urgency to urinate and increased daytime urinary frequency.

Table 3 - Pre- and post-radiotherapy pelvic symptoms [n (\%)]

\begin{tabular}{lcccccc}
\hline \multicolumn{1}{c}{ Pelvic symptoms } & \multicolumn{2}{c}{$\begin{array}{c}\text { Pre-RT group } \\
(n=12)\end{array}$} & \multicolumn{2}{c}{$\begin{array}{c}\text { Post-RT \#1 group } \\
(n=10)\end{array}$} & \multicolumn{2}{c}{$\begin{array}{c}\text { Post-RT \#2 group } \\
(n=11)\end{array}$} \\
\hline & Pre-RT & Post-RT & Pre-RT & Post-RT & Pre-RT & Post-RT \\
Urinary complaints & & & & & & \\
Asymptomatic & $0(0)$ & - & $2(20)$ & $1(10)$ & $4(36.4)$ & $4(36.4)$ \\
Obstructive & $1(8.3)$ & - & $5(50)$ & $1(10)$ & $3(27.3)$ & $0(0)$ \\
Irritative & $3(25)$ & - & $0(0)$ & $3(30)$ & $0(0)$ & $5(54.5)$ \\
Nocturia $<3$ x/night & $4(33.3)$ & - & $0(0)$ & $1(10)$ & $0(0)$ & $1(9.1)$ \\
Nocturia $\geq 3$ x/night & $6(50)$ & - & $1(10)$ & $7(70)$ & $1(9.1)$ & $4(36.4)$ \\
UI & $5(41.7)$ & - & $0(0)$ & $2(20)$ & $1(9.1)$ & $5(45.5)$ \\
\hline
\end{tabular}


Table 3 - Pre- and post-radiotherapy pelvic symptoms [n (\%)]

(Conclusion)

\begin{tabular}{lcccccc}
\hline \multicolumn{1}{c}{ Pelvic symptoms } & \multicolumn{2}{c}{$\begin{array}{c}\text { Pre-RT group } \\
(n=12)\end{array}$} & \multicolumn{2}{c}{$\begin{array}{c}\text { Post-RT \#1 group } \\
(n=10)\end{array}$} & \multicolumn{2}{c}{$\begin{array}{c}\text { Post-RT \#2 group } \\
(n=11)\end{array}$} \\
\hline Anorectal complaints & Pre-RT & Post-RT & Pre-RT & Post-RT & Pre-RT & Post-RT \\
Anal pain & $0(0)$ & - & $1(10)$ & $0(0)$ & $0(0)$ & $0(0)$ \\
Constipation & $0(0)$ & - & $0(0)$ & $0(0)$ & $0(0)$ & $1(9.1)$ \\
Proctitis & $0(0)$ & - & $0(0)$ & $0(0)$ & $0(0)$ & $1(9.1)$ \\
Al and fecal urgency & $0(0)$ & - & $0(0)$ & $1(0)$ & $0(0)$ & $0(0)$ \\
Sexual complaints & & & & & & \\
ED & $12(100)$ & - & $6(60)$ & $4(40)$ & $6(54.5)$ & $4(36.4)$ \\
\hline
\end{tabular}

Note: Al, anal incontinence; Constipation, difficulty in evacuation; ED, erectile dysfunction; Irritative, include increased daytime frequency and urinary urgency; Nocturia, night micturition; Obstructive, include a weak or intermittent jet, a sensation of incomplete bladder emptying, and the need for effort to complete urination; Proctitis, Inflammation of the anus/rectum; RT, radiotherapy; UI, urinary incontinence.

State of urinary continence and impact of incontinence on daily living activities

The evaluation of UI and its impact on DLA was measured by the ICIQ-SF, in accordance with the questions analyzed by the questionnaire, are presented below (Table 4). There was no significant difference in the ICIQ score between groups.

Table 4 - Urinary incontinence and its impact on daily life activities [n (\%)]

\begin{tabular}{|c|c|c|c|}
\hline ICIQ-SF & $\begin{array}{l}\text { Pre-RT } \\
\text { group } \\
(n=12)\end{array}$ & $\begin{array}{l}\text { Post-RT } \\
\# 1 \text { group } \\
(n=10)\end{array}$ & $\begin{array}{c}\text { Post-RT } \\
\text { \#2 group } \\
(n=11)\end{array}$ \\
\hline \multicolumn{4}{|l|}{ Frequency (Question 3) } \\
\hline Never & $7(58.3)$ & $8(80)$ & $6(54.5)$ \\
\hline$\geq$ once per week & $1(8.3)$ & $0(0)$ & $1(9.1)$ \\
\hline 2-3 times per week & $1(8.3)$ & $0(0)$ & $1(9.1)$ \\
\hline once per day & $0(0)$ & $1(10)$ & $1(9.1)$ \\
\hline Several times per day & $3(25)$ & $1(10)$ & $2(18.2)$ \\
\hline \multicolumn{4}{|l|}{ All the time } \\
\hline Never & $7(58.3)$ & $8(80)$ & $6(54.5)$ \\
\hline Small & $4(33)$ & $1(10)$ & $1(9.1)$ \\
\hline Moderate & $0(0)$ & $1(10)$ & $4(36.4)$ \\
\hline Large & $1(8.3)$ & $0(0)$ & $0(0)$ \\
\hline \multicolumn{4}{|l|}{ Impact (Question 5) } \\
\hline None & 7 (58.3) & $8(80)$ & $6(54.5)$ \\
\hline Mild & $2(16.7)$ & $2(20)$ & $1(9.1)$ \\
\hline
\end{tabular}

(To be continued)
(Conclusion)

Table 4 - Urinary incontinence and its impact on daily life activities [n (\%)]

\begin{tabular}{lccc}
\hline \multicolumn{1}{c}{ ICIQ-SF } & $\begin{array}{c}\text { Pre-RT } \\
\text { group } \\
(n=12)\end{array}$ & $\begin{array}{c}\text { Post-RT } \\
\text { 1 group } \\
(n=10)\end{array}$ & $\begin{array}{c}\text { Post-RT } \\
\text { \#2 group } \\
(n=11)\end{array}$ \\
\hline Moderate & $1(8.3)$ & $0(0)$ & $2(18.2)$ \\
Severe & $1(8.3)$ & $0(0)$ & $2(18.2)$ \\
Very Severe & $1(8.3)$ & $0(0)$ & $0(0)$ \\
UI Characterization (Question 6) & & & \\
UUI & $3(60)$ & $1(50)$ & $3(60)$ \\
EUI & $2(40)$ & $1(50)$ & $1(20)$ \\
MUI & $0(0)$ & $0(0)$ & $1(20)$ \\
ICIQ Score & 9.6 & 9.8 & 11.8 \\
\hline
\end{tabular}

Note: EUI, effort urinary incontinence; ICIQ-SF, International Consultation on Incontinence Questionnaire - short form; MUI, mixed urinary incontinence; RT, radiotherapy; UUI, urge urinary incontinence.

Quality of life

In a QoL analysis as assessed by the WHOQOL-BREF (Table 5), there was a significant difference in the questionnaire scores between the Pre-RT and Post-RT \#1 groups and Post-RT \#1 and Post-RT \#2 groups in physical, environmental and overall QoL. 
Table 5 - Analysis of WHOQOL-BREF questionnaire [mean \pm SD]

\begin{tabular}{|c|c|c|c|c|c|c|c|c|c|}
\hline \multirow{2}{*}{$\begin{array}{l}\text { Domains } \\
\text { Physical }\end{array}$} & \multicolumn{2}{|c|}{$\begin{array}{l}\text { Pre-RT vs Post-RT \# } \\
(n=12) \text { vs }(n=10)\end{array}$} & \multirow{2}{*}{$\begin{array}{c}p \\
0.01\end{array}$} & \multicolumn{2}{|c|}{$\begin{array}{l}\text { Pre-RT vs Post-RT \#2 } \\
(n=12) \text { vs }(n=11)\end{array}$} & \multirow{2}{*}{$\begin{array}{c}p \\
0.9\end{array}$} & \multicolumn{2}{|c|}{$\begin{array}{l}\text { Post-RT \#1 vs Post-RT \#2 } \\
\quad(n=10) \text { vs }(n=11)\end{array}$} & \multirow{2}{*}{$\begin{array}{c}p \\
0.02\end{array}$} \\
\hline & $69.0 \pm 3.9$ & $83.2 \pm 4.7$ & & $69.0 \pm 3.9$ & $68.3 \pm 5.5$ & & $83.2 \pm 4.7$ & $68.3 \pm 5.5$ & \\
\hline Psychological & $3.5 \pm 3.2$ & 68.1 & 0.1 & 2 & 62.5 & 1.0 & 1.0 & & 0.3 \\
\hline Social & $6 \pm 2.3$ & $65.8 \pm 5.0$ & 0 & $6 \pm 2.3$ & $65.1 \pm 5.0$ & 0.7 & 65.8 & 5.0 & 1.0 \\
\hline Environmental & $0.7 \pm 2.8$ & $70.9 \pm$ & 0.02 & $.7 \pm 2.8$ & $59.4 \pm$ & 0.9 & $.9 \pm 3.4$ & .5 & 0.02 \\
\hline Overall QoL & $62.5 \pm 5.5$ & $81.3 \pm 4.3$ & 0.02 & $62.5 \pm 5.5$ & $59.1 \pm 8.1$ & 0.9 & $81.3 \pm 4.3$ & $59.1 \pm 8.1$ & 0.04 \\
\hline
\end{tabular}

Note: QoL, quality of life; RT, radiotherapy; WHOQOL-BREF, World Health Organization Quality of Life - Brief.

\section{Discussion}

Among the different treatment modalities for PC, RT has been noteworthy because of its importance in the local control of disease and comparatively fewer side-effects [13]. However, despite advances that allows modulation of the radiation intensity to allow maximum preservation of healthy organs, some areas, such as the bladder and rectum, are particular sensitive and can tolerate small doses of radiation, leading to varying degrees of toxicity.

Ghadjar and collaborators [14] studied the acute and late effects of RT in 39 men with PC. Grade 2 gastrointestinal toxicity (particularly diarrhea, pain, and rectal bleeding) varied from $3 \%$ to $8 \%$ of cases. No patients had Grade 3 toxicity. In the follow-up period (total of two years), Grade 2 toxicity was found to decrease with time, reaching $0 \%$ by the end of the follow-up period. These data corroborate our study, where we observed that gastrointestinal and anorectal complaints were uncommon.

The same study also showed that $56 \%$ of patients had Grade 2 genitourinary toxicity (dysuria, UI, urinary retention, increased urinary frequency/ urgency, and hematuria). This dropped to $28 \%$ later in the follow-up period. There were no cases of Grade 4 genitourinary toxicity [14]. In our study, irritative symptoms (urinary urgency and daytime frequency) and nocturia, when considered together, were more frequent in the Post-RT \#1 group. However, a decrease in these symptoms was not widely observed in the Post-RT \#2 group. This can be explained by the higher number of incontinent patients in the Post-RT \#2 group ( $45.5 \%, n=5$ ), who tend to have a greater prevalence of urge urinary incontinence (UUI) $(n=4)$. Symptoms such as urinary urgency, increased urinary frequency and nocturia are characteristic of
UUI. Other study [10] also found that late side effects can be particularly more relevant in chronic lesions in adjacent tissues.

Erectile dysfunction (ED) was another prevalent complaint in the study. The ED rates found here corroborate the findings of two prospective studies, which showed a 30-40\% incidence of ED in patients between one and two years post-RT $[15,16]$.

The use of specific questionnaires for evaluation of symptoms is important in defining the type of complaint, and its severity and impact on DLA and QoL. Compared to women, the number of specific questionnaires for urinary complaints validated in Portuguese for men is low. The ICIQ-SF is a questionnaire validated for both sexes in the Brazilian population [11]. Other studies have also utilized the same questionnaire in men [17 - 19]. A Brazilian study [20] recently analyzed the correlation between the ICIQ-SF and urodynamic findings in men with UI after RP, representing the first study to address this correlation in men. Despite the correlations found in women, the total ICIQ-SF score could not differentiate whether sphincter incontinence or bladder dysfunction was the main cause of UI in that study. This finding confirms the hypothesis that it is not possible to determine the main cause of post-RP UI based on subjective assessment alone. The authors suggest, therefore, that the ICIQ-SF was designed to generally assess UI symptoms, LUTS and its impact on the QoL of men and women [20]. This was the purpose of our study, where ICIQ-SF was chosen as an easily applied and understood questionnaire to assess the presence, severity and impact of urinary loss in DLA.

The efficacy of a particular type of cancer treatment is assessed by biomedical parameters such as tumor shrinkage, progression-free survival, 
overall survival, and toxicity. However, these results also need to be measured in terms of outcome of functionality of the patient and their psychological health. Hence, there is a need to establish the impact of the disease and its treatment on the QoL. A prospective cohort study evaluated the QoL of men with PC who underwent RP or RT. Starting with the pre-treatment and a follow-up examination up to five years afterward, 704 patients with localized PC (low or intermediate risk) were recruited between 2003 and 2005 by Ferrer and collaborators [10]. QoL was assessed by the Expanded Prostate Cancer Index Composite (EPIC) questionnaire. Results showed that the impact of brachytherapy on QoL was restricted to the urinary complaints without intestinal complaints or adverse sexual effects. Initially, the impact of UI was minor but increased over the five years post-RT and the impact of the irritative and obstructive symptoms was moderate throughout the entire follow-up period, similar data that we found in our study. Function worsened slightly over time after RT.

Other study [21] also reinforces our findings in the QoL assessment. The study explored the longterm impact of acute and/or late RT symptoms on QoL. The study monitored 298 patients prospectively in four distinct periods: (A) before RT; (B) at the last RT session; (C) two months after RT; and (D) one year after RT. Evaluation was performed using the EPIC questionnaire. Correlation and sub-group analysis showed a strong relationship between urinary and bowel symptoms before and after RT. In contrast, the absolute scores did not have the same correlation. Long-term changes can be predicted by post-RT acute alterations. That is, patients reporting urinary and bowel problems ranging from major to moderate during timeframe $\mathrm{C}$ had great to moderate inconvenience due to the same complaints in $\geq 50 \%$ of these patients during D. In addition, changes in QoL scores during B were independently predictive of poorer longterm QoL, despite the different QoL assessment tools used here compared to the study above [21]. Our results reinforce the same conclusions of the Pinkawa et al: patients who had no improvement in acute toxicity were candidates for a closer followup examination to identify possible preventive actions that could reduce the high probability of long-term problems.
Various treatment modalities are available to manage UI, including pharmacological therapy, behavioral therapy and surgical treatment. In 1948, Kegel first advocated PFMT to enhance urethral resistance and promote urinary control [22]. The application of Kegel exercises has been broadened to various applications but the concentration continues to be for UI secondary to sphincteric deficiency. Many studies have shown that the success of PFMT for IU depends on the degree and duration of treatment, and close supervision by a physical therapist.

Therefore, Physical Therapy is a therapeutic option without side effects and lower cost. It may contribute to improvement of pelvic complaints and symptoms and consequent improvement in QoL. PFMT is a first-line treatment used to restore pelvic floor or bladder function. PFMT trains subjects to isolate and correctly contract the pelvic floor muscles (PFM) to increase strength and endurance. Repeated contractions are thought to improve urinary control through increased support for the detrusor muscle and urethral sphincter [23].

However, the benefit of PFMT and reeducation for male UI has not been well studied. Most studies focus on the PFMT in men undergoing RP showing promising results [24 - 26]. But, patients undergoing RT are not studied. Additional trials are needed to confirm the effectiveness of this conservative treatment option in the patients treated with RT.

\section{Limitations}

Among the limitations of our study, first is the inclusion of men who were prostatectomized and submitted to HT.

$\mathrm{RP}$ is one of the most frequently used alternative therapies for PC. Although it has a high cure rate, surgery is often followed by complications, with UI and ED the most important. From our prostatectomized sample population $(n=8)$, five patients complained of UI, though two had UI prior to RT. The most important cause of UI in adult males was a sphincter injury due to prostate surgery to reduce bladder urethral junction to maintain urinary continence, creating greater demands of the PFM [27]. The overall prevalence of UI after RP ranges from $2 \%$ to $60 \%$, although rates decrease with time [28]. Bladder dysfunctions may be present in these cases. 
However, the prevalence of UI post-RP is higher due to sphincter deficiency (88\%) and lower due to bladder dysfunction $[29,30]$, according to the urodynamic findings. These observations are confirmed by our study, as characterization of UI in post-RP patients is associated with effort UI.

From our sample of prostatectomized patients, seven complained of pre-RT ED (87.6\%). ED post$\mathrm{RP}$ is multifactorial, though the main cause is of neurogenic origin due to the cavernous nerve lesion during the dissection of the cavernous neurovascular bundle. ED can also have a psychogenic and/or vasculogenic origin. Post-RP ED rates range from $10-90 \%$ [31], as seen in the present study.

Little data is available on the effect of HT on the lower urinary tract. A research [32] studied the possible association between the severity of LUTS and serum levels of sex hormones in men with symptomatic benign prostatic hyperplasia. They concluded that severity of urinary symptoms is associated with age and testosterone serum levels. However, age was the only predisposing factor for prostate volume in the statistical analysis. Testosterone itself may not be the main driver of the effects on urinary tract structures that are anatomically and functionally related to LUTS [32]. However, other studies have showed that the androgen receptors are present in most of epithelial cells of the urethra and bladder [33] and discussed the role of testosterone and its metabolites in maintaining pelvic reflex activity of the autonomic nervous system in rats [34]. Additional large studies are required to confirm these preliminary results in humans [32].

Men who receive HT also report lower sexual activity, fewer sexual thoughts, and fewer spontaneous erections than men with normal testosterone levels [35]. This may explain the number of patients with ED in the pre-RT group.

Another factor would be the age and obesity. Age is the main risk factor for PC. Obesity also presents as an important risk factor for the development of cancer [1]. Both factors may also have some influence on LUTS. UI is not a normal part of aging, but age-related conditions and changes in bladder function and PFM can contribute to loss of sphincter control in the elderly. However, elderly are more prone to other factors associated with UI: comorbidities, polypharmacy, functional limitations, cognitive impairment, and prostate diseases [36, 37].
Although the included patients were mostly elderly, our sample was composed of men with good cognitive status, without functional limitations and important comorbidities. The sample also did not present relevant LUTS relative to the age before $\mathrm{RT}$. Thus, we believe that age is not a confounding factor for the data analyzed in this study. In relation to obesity, the increase in bladder pressure due to obesity would in turn increase afferent stimuli, leading to increased urinary urgency and frequency. However, men have higher fixation of the PFM and are, therefore, less susceptible to these forces, which prevents symptoms of increasing weight until a certain set point or significant obesity is reached [38]. On average, our sample was not composed of obese men with a BMI above $30 \mathrm{~kg} / \mathrm{m}^{2}$, but men with overweight.

Other limitations of this study include the short period of time used to develop a longitudinal study. We were not able to monitor the same patients before and after RT. However, the lack of studies in this field allowed us to survey the characteristics of these patients and trace the treatment outcomes for future research. Future investigations would involve identifying conservative approaches for symptom management leading to QoL improvement, especially in patients already presenting with pelvic symptoms before RT.

However, despite the limitations, our main motivation with this research was to outline the scenario in which these patients are inserted, analyzing its context and thereby stimulate a more comprehensive investigation of the matter. Understanding the pelvic symptoms more prevalent after RT in the PC treatment may help to understand the impact of treatment on patients and to stimulate the search for strategies to prevent or minimize these complaints with consequent improvement in QoL and the patient functionality.

\section{Conclusion}

The acute effect of RT was characterized by a higher prevalence of LUTS (especially urinary urgency and nocturia). The Post-RT \#2 group showed greater impact on DLA due to the higher prevalence of post-RT UI and poorer QoL scores compared to recently irradiated patients. 


\section{Aknowledgements}

To the Foundation for Research Support of the State of São Paulo (FAPESP) for the financial support (2012/14306-1).

\section{References}

1. INCA - Instituto Nacional de Câncer José Alencar Gomes da Silva. Coordenação de Prevenção e Vigilância. Estimativa 2016: Incidência de Câncer no Brasil. Rio de Janeiro: INCA; 2015. 122 p.

2. D'Amico AV, Whittington R, Malkowicz SB, Schultz D, Blank K, Broderick GA, et al. Biochemical outcome after radical prostatectomy, external beam radiation therapy, or intersticial radiation therapy for clinic localized prostate cancer. JAMA. 1998;280(11):969-74.

3. ACS - American Cancer Society. Prostate Cancer. Atlanta: American Cancer Society; 2012 [cited 2017 Jan 24] Available from: https://tinyurl.com/ ycd5yn4l

4. NCCN - National Comprehensive Cancer Network. NCCN Clinical Practice Guidelines in Oncology. Washington: NCCN Inc; 2014. 85 p.

5. Shao YH, Albertsen PC, Roberts CB, Lin Y, Mehta AR, Stein MN, et al. Risk profiles and treatment patterns among men diagnosed as having prostate cancer and a prostate-specific antigen level below $4.0 \mathrm{ng} / \mathrm{ml}$. Arch Intern Med. 2010;170(14):1256-61.

6. Haab F, Beley S, Cornu JN, Culine S, Cussenot 0 , Hennequin C. Urinary and sexual disorders following localised prostate cancer management. Bull Cancer 2010;97(12):1537-49.

7. Jackson J, Murthy V, Dearnaley D. External beam radiotherapy for prostate cancer; in Hoskin P. Radiotherapy in pratice: External Beam Therapy. Oxford: Oxford University Pres; 2006. p. 181-211.

8. Santos Jr JCM. Radioterapia: lesões inflamatórias e funcionais de órgãos pélvicos. Rev Bras Coloproct. 2006;26(3):348-55.
9. Emara AM, Chadwick E, Nobes JP, Abdelbaky AM, Laing RW, Langley SE. Long-term toxicity and quality of life up to 10 years after low-dose rate brachytherapy for prostate cancer. BJU Int. 2012;109(7):994-1000.

10. Ferrer M, Guedea F, Suarez JF, Macias V, Marino A, Hervas A, et al. Quality of life impact of treatments for localized prostate cancer: Cohort study with a 5year follow-up. Radiother Oncol. 2013;108(2):306-13.

11. Tamanini JT, Dambros M, D'Ancona CA, Palma PC, Rodrigues Netto Jr N. Validation of the "International Consultation on Incontinence Questionnaire - Short Form" (ICIQ-SF) for Portuguese. Rev Saude Publica. 2004;38(3):438-44.

12. Fleck MPA, Louzada S, Xavier M, Chachamovich E, Vieira G, Santos, et al. Aplicação da versão em português do instrumento abreviado de avaliação da qualidade de vida "WHOQOL-bref". Rev Saude Publica. 2000;34(2):178-83.

13. Dearnaley DP, Sydes MR, Graham JD, Aird EG, Bottomley D, Cowan RA, et al. Escalated-dose versus standard-dose conformal radiotherapy in prostate cancer: first results from the MRC RT01 randomised controlled trial. Lancet Oncol. 2007;8(6):475-87.

14. Ghadjar P, Vock J, Vetterli D, Manser P, Bigler R, Tille J, et al. Acute and late toxicity in prostate cancer patients treated by dose escalated intensity modulated radiation therapy and organ tracking. Radiat Onco. 2008;3:1-8.

15. Pinkawa M, Gagel B, Piroth MD, Fischedick K, Asadpour B, Kehl M, et al. Erectile dysfunction after external beam radiotherapy for prostate cancer. Eur Urol. 2009;55(1):227-34.

16. Van der Wielen GJ, van Putten WL, Incrocci L. Sexual function after three-dimensional conformal radiotherapy for prostate cancer: results from a dose-escalation trial. Int J Radiat Oncol Biol Phys. 2007;68(2):479-84. 
17. Acar C, Schoffelmeer CC, Tillier C, de Blok W, van Muilekom E, van der Poel HG. Quality of life in patients with low-risk prostate cancer. A comparative retrospective study: brachytherapy versus robotassisted laparoscopic prostatectomy versus active surveillance. J Endourol. 2014;28(1):117-24.

18. Treiyer A, Anheuser P, Butow Z, Steffens J. A single center prospective study: prediction of postoperative general quality of life, potency and continence after radical retropubic prostatectomy. J Urol 2011;185(5):1681-5.

19. Twiss CO, Fischer MC, Nitti VW. Comparison between reduction in 24-hour pad weight, International Consultation on Incontinence-Short Form (ICIQ-SF) score, International Prostate Symptom Score (IPSS), and Post-Operative Patient Global Impression of Improvement (PGI-I) score in patient evaluation after male perineal sling. Neurourol Urodyn. 2007;26(1):8-13.

20. Reis RB, Cologna AJ, Machado RD, Machado MT, Nogueira L, Reis LO, et al. Lack of association between the ICIQ-SF questionnaire and the urodynamic diagnosis in men with post radical prostatectomy incontinence. Acta Cir Bras 2013;28(Suppl 1):37-42.

21. Pinkawa M, Holy R, Piroth MD, Fischedick K, Schaar $S$, Szekely-Orban D, et al. Consequential late effects after radiotherapy for prostate cancer - a prospective longitudinal quality of life study. Radiat Oncol. 2010;5:1-9.

22. Kegel AH. Physiologic therapy for urinary stress incontinence. J Am Med Assoc. 1951;146(10):915-7.

23. Bø K. Pelvic floor muscle training is effective in treatment of female stress urinary incontinence, but how does it work? Int Urogynecol J Pelvic Floor Dysfunct. 2004;15(2):76-84.

24. Patel MI, Yao J, Hirschhorn AD, Mungovan SF. Preoperative pelvic floor physiotherapy improves continence after radical retropubic prostatectomy. Int J Urol. 2013;20(10):986-92.
25. Nilssen SR, Morkved S, Overgård M, Lydersen S, Angelsen A. Does physiotherapist-guided pelvic floor muscle training increase the quality of life in patients after radical prostatectomy? A randomized clinical study. Scand J Urol Nephrol. 2012;46(6):397-404.

26. Filocamo MT, Marzi VL, Del Popolo G, Cecconi F, Marzocco M, Tosto A, et al. Effectiveness of early pelvic floor rehabilitation treatment for post-prostatectomy incontinence. Eur Urol. 2005;48(5):734-8.

27. Kakihara CT, Sens YAS, Ferreira U. Efeito do treinamento funcional do assoalho pélvico associado ou não à eletroestimulação na incontinência urinária após prostatectomia radical. Rev Bras Fisioter. 2007;11(6):481-6.

28. Buckley BS, Lapitan MCM. Prevalence of urinary incontinence in men, women, and children - Current evidence: Findings of the Fourth International Consultation on Incontinence. Urology. 2010;76(2):265-70.

29. Groutz A, Blaivas JG, Chaikin DC, Resnick NM, Engleman K, Anzalone D, et al. Noninvasive outcome measures of urinary incontinence and lower urinary tract symptoms: a multicenter study of micturition diary and pad tests. J Urol 2000;164(3 Pt 1):698-701.

30. Groutz A, Blaivas JG, Chaikin DC, Weiss JP, Verhaaren M. The pathophysiology of post-radical prostatectomy incontinence: a clinical and video urodynamic study. J Urol 2000;163(6):1767-70.

31. Coelho RF, Colombo Jr JR, Patel V. Status atual da prostatectomia robô-assistida; in Faria EF, Seabra DDG, Machado RD, editors. Uro-oncologia: dúvidas e controvérsias. Ribeirão Preto: Novo Conceito; 2009. p. 179-92.

32. Favilla V, Cimino S, Castelli T, Madonia M, Barbagallo I, Morgia G. Relationship between lower urinary tract symptoms and serum levels of sex hormones in men with symptomatic benign prostatic hyperplasia. BJU Int. 2010;106(11):1700-3. 
33. Rosenzweig BA, Bolina PS, Birch L, Moran C, Marcovici I, Prins GS. Location and concentration of estrogen, progesterone, and androgen receptors in the bladder and urethra of the rabbit. Neurourol Urodyn. 1995;14(1):87-96.

34. Keast JR. The autonomic nerve supply of male sex organs - an important target of circulating androgens. Behav Brain Res. 1999;105(1):81-92.

35. Finkelstein JS, Lee H, Burnett-Bowie SAM, Pallais JC, Yu EW, Borges L, et al. Gonadal steroids and body composition, strength, and sexual function in men. N Engl J Med. 2013;369:1011-22.

36. Aslan E, Beji NK, Erkan HA, Yalcin O, Gungor F. The prevalence of and the related factors for urinary and fecal incontinence among older residing in nursing homes. J Clin Nurs. 2009;18(230:3290-8.
37. Tamanini JT, Lebrão ML, Duarte YA, Santos JL, Laurenti R. Analysis of the prevalence of and factors associated with urinary incontinence among elderly people in the Municipality of São Paulo, Brazil: SABE Study (Health, Wellbeing and Aging). Cad Saude Publica. 2009;25(8):1756-62.

38. Link CL, Steers WD, Kusek JW, McKinlay JB. The association of adiposity and overactive bladder appears to differ by gender: results from the Boston Area Community Health survey. J Urol. 2011;185(3):955-63.

Received on $04 / 30 / 2016$

Recebido em 30/04/2016

Approved on $06 / 21 / 2017$

Aprovado em 21/06/2017 